c) American Dairy Science Association, 2005.

\title{
Effect of Increasing Oil from Distillers Grains or Corn Oil on Lactation Performance
}

\author{
C. Leonardi, ${ }^{*}$ S. Bertics, and L. E. Armentano \\ Department of Dairy Science, University of Wisconsin, Madison 53706
}

\begin{abstract}
The objective of this study was to evaluate production response and more specifically percentage and yield of fat in milk from dairy cows fed distillers grains with added solubles (DGS). It was hypothesized that the oil present in DGS would decrease milk fat yield. Four dietary treatments consisted of dried DGS replacing soybean meal and soybean hulls. The DGS inclusion rates as a percentage of dry matter (DM) were $0,5,10$, and $15 \%$ DGS. To determine the role of oil in DGS, a fifth diet similar to 0\% DGS with added corn oil (OIL) was included. Twenty multiparous Holsteins were assigned to a replicated, $5 \times 5$ Latin Square design with periods of $21 \mathrm{~d}$. Diets were formulated to have similar crude protein and neutral detergent fiber (NDF) concentration. Feeding OIL or 15\% DGS resulted in similar production of milk, milk protein, and milk fat. Increasing dietary DGS linearly increased milk production and milk true protein yield. Adding corn oil increased milk yield and, although milk true protein yield also tended to increase with oil, milk true protein concentration decreased. The addition of DGS or OIL did not significantly change fat yield from 0\% DGS; however, fat concentration in milk was significantly decreased by DGS due to increased fluid milk production. In diets containing approximately $28 \% \mathrm{NDF}$, cottonseed, blood and fish meal, feeding DGS to bring total dietary fatty acids to 5\% of diet DM increased milk and milk protein yield without decreasing milk fat yield. Reduced proportions of shorter chain fatty acids and increased proportions of longer chain fatty acids in milk as dietary fatty acid content increased suggests that de novo fatty acid synthesis in the mammary gland was inhibited but this was offset by increased secretion of long-chain fatty acids, presumably absorbed from the diet. Therefore, our hypothesis that feeding corn oil either as DGS or
\end{abstract}

Received February 18, 2005.

Accepted April 18, 2005.

Corresponding author: Louis E. Armentano; e-mail: learment@ facstaff.wisc.edu.

*Current address: Department of Experimental Statistics, Louisiana State University, Baton Rouge, LA 70803.

as pure corn oil would decrease milk fat yield was not correct.

(Key words: milk production, distillers grains with solubles)

Abbreviation key: DGS = distillers grains with solubles, $\mathbf{E E}=$ ether extract, $\mathbf{O I L}=$ diet containing corn oil but no DGS.

\section{INTRODUCTION}

Distillers grains with solubles (DGS) is a by-product of the ethanol industry. The chemical composition of corn DGS depends on the fermentation procedure and corn characteristics. Fourteen new ethanol plants were built in the United States in 2002 and 2003, and at least 54 more plants are being planned (Wisner and Baumel, 2004). Ether extract (EE) content of DGS from newer plants may be greater than EE in DGS from older plants. From 1997 to 1999, samples of DGS were collected from 10 new and 1 older ethanol plants in Minnesota and South Dakota (Spiehs et al., 2002). The average $\mathrm{CP}, \mathrm{NDF}$, and $\mathrm{EE}$ concentrations for the new plants were $30.2,42.1$, and $10.9 \%$ and for the older plant were $28.1,35.4$, and $8.2 \%$, respectively. Ether extract ranged from 10.2 to $11.7 \%$ in the newer plants. The EE content of 464 samples of corn DGS was reported as $10.0 \%$ with an SD of $3.4 \%$ by NRC (2001).

In 2 studies, the dietary inclusion of $2 \%$ or more of oil reduced milk fat percentage and yield (Griinari et al., 1998; Dhiman et al., 2000). Replacing 2 or more percentage units of high moisture corn with soybean oil decreased milk fat percentage and yield (Dhiman et al., 2000). The inclusion of 4\% (as-fed basis) corn oil decreased milk fat percentage and yield when added to an alfalfa hay-based diet containing $14.8 \%$ NDF but not when added to an alfalfa hay-based diet containing $32.1 \%$ NDF (Griinari et al., 1998). Increasing the DGS dietary percentage by replacing soybean meal or corn grain will result in increased dietary EE concentration. This increase is greater when EE content of DGS is above average.

Studies conducted in the last 10 yr reported that feeding corn DGS did not significantly affect milk fat percentage or yield (Powers et al., 1995; Birkelo et al., 
2004). However, in most experiments, either the overall dietary EE concentration was low or it was confounded with differences in dietary NDF concentration. Adding DGS in place of low fat, low fiber concentrates will increase dietary oil, which could reduce milk fat secretion, but will also increase dietary NDF, which can increase milk fat secretion. When dietary concentration of total fatty acid was maintained constant and milk fat concentration was decreased by removing alfalfa forage NDF, adding NDF from distillers grains returned milk fat concentration to normal (Clark and Armentano, 1993). Powers et al. (1995) reported that feeding DGS in place of soybean meal and corn grain did not affect milk fat percentage or yield. Although feeding DGS increased dietary EE concentration from 4.4 to above $5 \%$, NDF concentration was also increased from 32 to approximately $39 \%$. In a more recent study, feeding wet DGS instead of rolled corn and soybean meal tended to increase milk fat percentage and yield (Birkelo et al., 2004). Although EE increased from 3.1 to $5.1 \%$, NDF concentration was also increased from 28.3 to $42.9 \%$ (Birkelo et al., 2004). The concurrent increase in dietary NDF and EE concentration limits the ability to discern the potential negative effect of distillers grains oil from the positive effects of increased NDF on milk fat percentage and yield.

The objective of this study was to evaluate production response and more specifically percentage and yield of fat in milk from dairy cows fed DGS at various inclusion rates with similar dietary NDF concentration. Furthermore, we wanted to verify if the corn oil present in DGS was solely responsible for the decreased milk fat yield.

\section{MATERIALS AND METHODS}

\section{Animals and Diets}

Twenty multiparous lactating Holstein cows were assigned to a replicated, $5 \times 5$ Latin Square design with periods of $21 \mathrm{~d}$. Cows were randomly assigned to each square. At the beginning of the study, cows averaged ( \pm SD) $93 \pm 32 \mathrm{DIM}$ and produced $45.9 \pm 6.4 \mathrm{~kg}$ of milk daily. The sequence of treatments differed by square and was selected to balance for carryover effects. Cows were housed and fed individually in the same barn in either stanchions or tie stalls and had free-choice access to water. The Animal Care Committee of the College of Agricultural and Life Sciences of the University of Wisconsin-Madison approved all animal procedures.

Diets were mixed once daily and fed for ad libitum intake twice daily at 1100 and $1600 \mathrm{~h}$. The amount of feed offered was adjusted daily to obtain approximately $10 \%$ refusals (as-fed basis). Cows were allowed to exercise daily from $0800 \mathrm{until} 1100 \mathrm{~h}$ and had access to feed for approximately $19 \mathrm{~h} / \mathrm{d}$. Diets were formulated to meet or exceed the National Research Council (NRC, 2001) nutrient allowances for a lactating dairy cow 90 DIM, weighing $680 \mathrm{~kg}$, eating $26.9 \mathrm{~kg}$ of DM daily, producing $45 \mathrm{~kg}$ of milk daily, and having a milk fat percentage of 3.5, and a milk true protein percentage of 3.0. All diets contained $27.0 \%$ corn silage, $18.0 \%$ alfalfa silage, $5.1 \%$ cottonseed and $49.9 \%$ concentrate (DM basis, Table 1), and had similar CP and NDF concentration. Dietary nutrient content was calculated based on analysis of individual forages, cottonseed, and concentrate mixtures and the dietary proportions of each used (Table 2). Urea was added as required to meet minimum RDP requirements (NRC, 2001). Four treatments consisted of DGS replacing soybean meal and soybean hulls at various inclusion rates. The dietary percentages of DGS on a DM basis were: $0,5,10$, and $15 \%$ DGS. A single batch of dried DGS was obtained for the entire experiment from Badger State Ethanol (Monroe, WI). It was hypothesized that the oil present in DGS would decrease milk fat yield. However, because adding DGS altered other dietary characteristics in addition to increasing fatty acid content, a fifth diet was included to test the effect of oil only. This diet (OIL) was formulated to be similar to the 0\% DGS diet but with added corn oil (Sysco, Baraboo, WI) replacing mainly soybean meal and corn grain ground. The amount of corn oil constituted $1.5 \%$ of dietary DM and was such that OIL had a total fatty acid concentration similar to the $15 \%$ diet.

\section{Sampling and Analysis}

Diets were adjusted weekly to account for forage DM fluctuation. Forage samples were collected once during the second week and twice during the last week of each experimental period. Cottonseed samples were collected once during the last week of each experimental period. A sample of DGS was collected during the preparation of the grain mixes fed during the last week of each experimental period. Remaining feeds were included in concentrate mixtures specific for each diet. These concentrate mixes were sampled once during each of the last 2 wk of every experimental period. All samples were dried at $60^{\circ} \mathrm{C}$ for $48 \mathrm{~h}$, ground to pass through a 1-mm screen (Wiley mill, Arthur H. Thomas, Philadelphia, PA) and analyzed for DM, OM, CP, NDF, and ADF. Within each feed, samples were composited by period and fatty acids were determined ( $\mathrm{n}=5$ for each feed or mix). Orts were sampled during the last 4 $\mathrm{d}$ of each period, and composited by animal proportionally to the weight of feed refused each day. The composite ort samples were dried at $60^{\circ} \mathrm{C}$ for $48 \mathrm{~h}$, and analyzed for DM and NDF. Intakes of DM and NDF were calculated utilizing dietary and orts DM and NDF data measured during the last week of each experimental period. 
Table 1. Diet composition.

\begin{tabular}{|c|c|c|c|c|c|}
\hline \multirow{2}{*}{ Item } & \multicolumn{5}{|c|}{ Diet $^{1}$} \\
\hline & $0 \%$ & $5 \%$ & $10 \%$ & $15 \%$ & OIL \\
\hline & \multicolumn{5}{|c|}{$(\mathrm{g} / 100 \mathrm{~g}$ of $\mathrm{DM})$} \\
\hline Corn silage $^{2}$ & 27.0 & 27.0 & 27.0 & 27.0 & 27.0 \\
\hline Alfalfa silage $^{3}$ & 18.0 & 18.0 & 18.0 & 18.0 & 18.0 \\
\hline Corn grain ground & 30.1 & 29.5 & 29.2 & 28.1 & 29.0 \\
\hline Cottonseed $^{4}$ & 5.1 & 5.1 & 5.1 & 5.1 & 5.1 \\
\hline Soybean meal, $48 \% \mathrm{CP}$ & 7.5 & 5.0 & 2.0 & & 6.5 \\
\hline Soybean hulls & 8.0 & 6.0 & 4.0 & 2.1 & 8.4 \\
\hline DGS $^{5}$ & $\ldots$ & 5.0 & 10.1 & 15.0 & \\
\hline Urea & $\ldots$ & 0.1 & 0.3 & 0.4 & 0.2 \\
\hline Porcine blood meal & 1.4 & 1.4 & 1.4 & 1.4 & 1.4 \\
\hline Fish meal & 1.0 & 1.0 & 1.0 & 1.0 & 1.0 \\
\hline Calcium carbonate & 0.7 & 0.7 & 0.7 & 0.7 & 0.7 \\
\hline Dicalcium phosphate & 0.1 & 0.1 & 0.1 & 0.1 & 0.1 \\
\hline Trace mineral salt ${ }^{6}$ & 0.7 & 0.7 & 0.7 & 0.7 & 0.7 \\
\hline Vitamin $\operatorname{mix}^{7}$ & 0.4 & 0.4 & 0.4 & 0.4 & 0.4 \\
\hline Corn oil ${ }^{8}$ & $\ldots$ & - & $\ldots$ & - & 1.5 \\
\hline
\end{tabular}

${ }^{1}$ Diets: $0,5,10$, or $15 \%$ DGS = diets containing distillers dried grains with solubles (DGS, DM basis); OIL = diet containing corn oil but no DGS; the amount of corn oil added was such that OIL and 15\% DGS had similar total fatty acid concentration.

${ }^{2}$ Corn silage was $33.1 \% \mathrm{DM}$ and contained (DM basis) $6.5 \% \mathrm{CP}, 39.4 \% \mathrm{NDF}, 23.8 \% \mathrm{ADF}, 4.2 \%$ ash and $2.5 \%$ fatty acids.

${ }^{3}$ Alfalfa silage was $38.0 \% \mathrm{DM}$ and contained (DM basis) $20.1 \% \mathrm{CP}, 37.3 \% \mathrm{NDF}, 31.6 \% \mathrm{ADF}, 10.2 \%$ ash and $2.0 \%$ fatty acids.

${ }^{4}$ Cottonseed was $90.4 \% \mathrm{DM}$ and contained (DM basis) $20.1 \% \mathrm{CP}, 48.3 \% \mathrm{NDF}, 39.7 \% \mathrm{ADF}, 3.8 \%$ ash and $18.0 \%$ fatty acids.

${ }^{5}$ DGS $=$ Distillers grains with solubles was $88.3 \pm 1.0 \% \mathrm{DM}$ and contained (DM basis) $28.7 \pm 0.9 \% \mathrm{CP}$, $25.9 \pm 2.3 \% \mathrm{NDF}, 14.7 \pm 1.7 \% \mathrm{ADF}, 10.8 \pm 0.5 \%$ fatty acids, and $4.5 \pm 0.2 \%$ ash (Badger State Ethanol, LLC, Monroe, WI).

${ }^{6}$ Contained $0.55 \% \mathrm{Mn}, 0.55 \% \mathrm{Zn}, 0.35 \% \mathrm{Fe}, 0.14 \% \mathrm{Cu}, 0.008 \% \mathrm{I}, 0.006 \%$ Se, and $0.002 \%$ Co.

${ }^{7}$ Contained $3304 \mathrm{IU} / \mathrm{g}$ of vitamin A, $1101 \mathrm{IU} / \mathrm{g}$ of vitamin D, and $11 \mathrm{IU} / \mathrm{g}$ of vitamin E.

${ }^{8}$ Sysco, Baraboo, WI.

Cows were milked twice daily. Milk production was recorded, and milk was sampled at each milking during the last $4 \mathrm{~d}$ of each period. Milk samples were analyzed for protein, fat, and lactose by infrared analysis (AgSource Milk Analysis Laboratory, Menomonie, WI) with a Fossmatic-605 (Foss Electric, Hillerød, Denmark) according to AOAC (1990). For determination of fatty acid profile, additional milk samples (4 per cow) were collected on d 20 and 21 of each experimental period, and pooled by cow within period in proportion to the volume of milk produced at each milking $(n=100)$. For fatty acid analysis, $330 \mathrm{mg}$ of milk fat was obtained by centrifuging $30 \mathrm{~mL}$ of whole milk at $17,800 \times \mathrm{g}$ at $8^{\circ} \mathrm{C}$ for 30 min. Lipid extraction and fatty acids methylation were performed according to the method described by Chouinard et al. (1999). Resulting fatty acid methyl esters were injected in a gas chromatograph (Perkin Elmer Autosystem, Norwalk, CT) equipped with a 100 $\mathrm{m}(0.25 \mathrm{~mm}$ i.d.) open tubular fused silica capillary column wall coated with CP-Sil 88 (Chrompack \#CP7489, Varian Inc., Walnut Creek, CA). Helium was the carrier gas. Each sample was analyzed under 2 different conditions. First, a temperature gradient run was performed to determine the fatty acid profile (50 to $190^{\circ} \mathrm{C}$ at $\left.4^{\circ} \mathrm{C} / \mathrm{min}\right)$. Second, an isothermal run $\left(160^{\circ} \mathrm{C}\right)$ was used to separate most trans-octadecenoic fatty acids. Peaks were identified utilizing individual fatty acids from Supelco Inc. (Bellefonte, PA), Sigma Chemical Co. (St. Louis, MO), and Matreya Inc. (Pleasant Gap, PA). Response correction factors for each fatty acid methyl ester were based on analysis of standard butter oil (CRM 164, Commission of the European Communities, Community Bureau of Reference, Brussels, Belgium) and were applied to adjust individual areas mass proportion.

The analytical DM was determined by oven drying at $100^{\circ} \mathrm{C}$ for $24 \mathrm{~h}$, and $\mathrm{OM}$ was determined by ashing at $550^{\circ} \mathrm{C}$ for $12 \mathrm{~h}$. Crude protein content was determined by microKjeldahl analysis (AOAC, 1990). Neutral detergent fiber was determined using $\alpha$-amylase (Sigma no. A3306; Sigma Chemical Co.) and sodium sulfite, and corrected for ash concentration according to Van Soest et al. (1991), adapted for Ankom ${ }^{200}$ Fiber Analyzer (Ankom Technology, Fairport, NY). Acid de- 
Table 2. Chemical composition of diets.

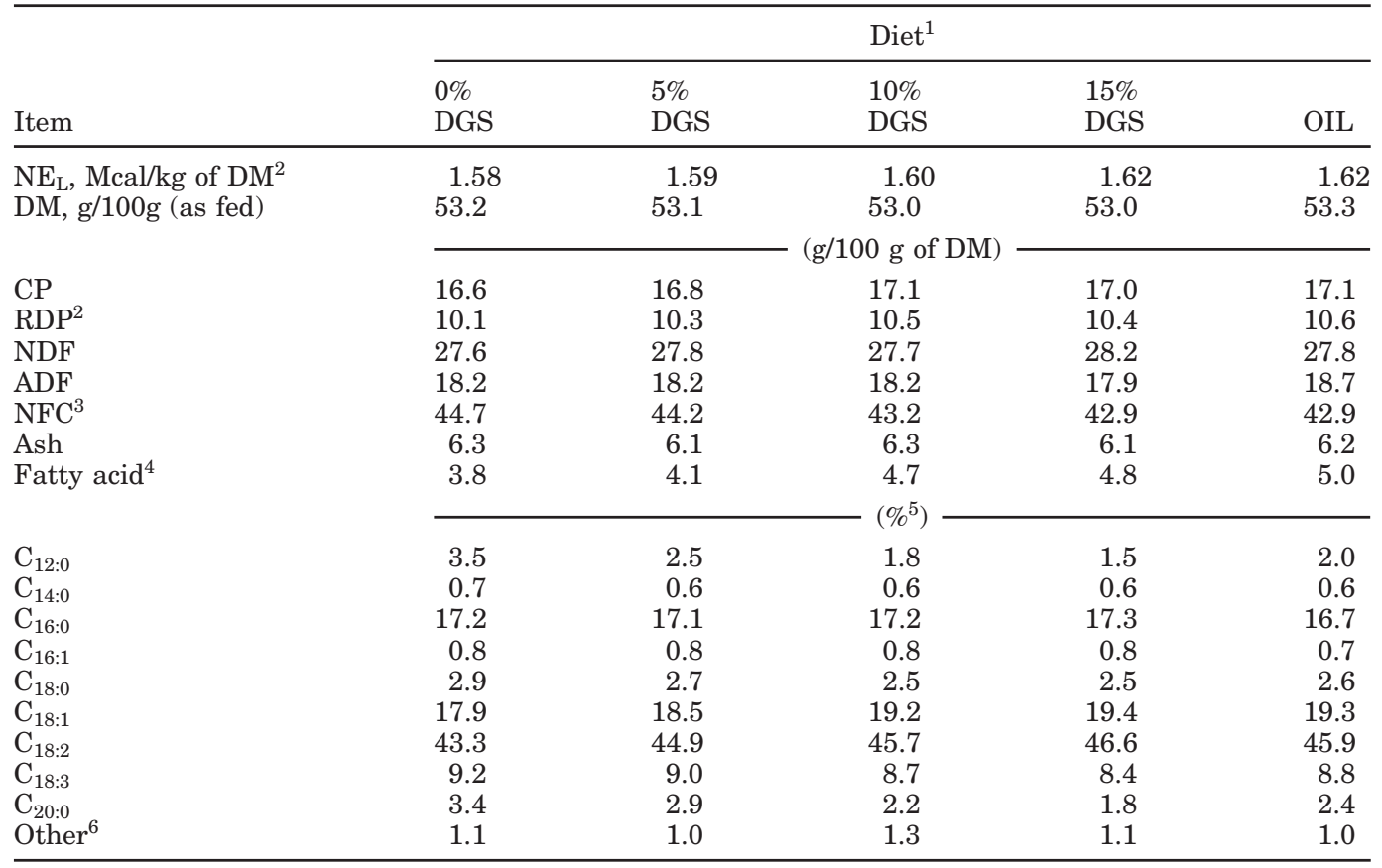

${ }^{1}$ Diets: $0,5,10$, or $15 \%$ DGS = diets containing distillers dried grains with solubles (DGS, DM basis); OIL = diet containing corn oil but no DGS; the amount of corn oil added was such that OIL and 15\% DGS had similar total fatty acid concentration. Chemical composition was mathematically calculated based on values for individual feedstuff or mixes.

${ }^{2}$ Values calculated based on NRC (2001) values for individual feedstuff.

${ }^{3} \mathrm{NFC}=100-($ fatty acid $+1+\mathrm{NDF}+\mathrm{CP}+$ ash $)$.

${ }^{4}$ Fatty acid represented the sum of $\mathrm{C}_{8: 0}$ to $\mathrm{C}_{22: 1}$.

${ }^{5}$ Feeds fatty acid relative percentages were calculated as area under the curve of individual fatty acid divided by total area under the curve. The total area was calculated by adding the area of each identified fatty acid.

${ }^{6}$ Other $=$ sum of $\mathrm{C}_{10: 0}, \mathrm{C}_{13: 0}, \mathrm{C}_{15: 0}, \mathrm{C}_{20: 1}, \mathrm{C}_{22: 1}$.

tergent fiber was determined using the method described by Goering and Van Soest (1970), adapted for Ankom ${ }^{200}$ Fiber Analyzer, and corrected for ash concentration. Feed fatty acids were determined by following the procedure described by Sukhija and Palmquist (1988), and represented the sum of $\mathrm{C}_{8: 0}$ to $\mathrm{C}_{22: 1}$. Feeds fatty acid relative percentages were calculated as area under the curve of individual fatty acid divided by total area under the curve. The total area was calculated by adding the area of each identified fatty acid. Ether extract of DGS was determined on one composite sample according to AOAC method 920.39 (1999) using diethyl ether in a Soxtec System HT6 (FOSS North America, Eden Prairie, MN). The NFC component was calculated as $100-(\mathrm{NDF}+\mathrm{EE}+\mathrm{CP}+$ ash $)$, where EE was calculated as fatty acid plus one (NRC, 2001). Reported NFC values are not corrected for neutral detergent insoluble N, and NPN.

\section{Statistical Analyses}

Data were analyzed using the MIXED procedure of SAS (SAS Institute, 1998). Four comparisons were tested: linear and quadratic effects of DGS, 0\% DGS vs. OIL, and $15 \%$ DGS vs. OIL. Daily DMI, milk production, and milk composition obtained during the last week of each experimental period were averaged within period to obtain one observation per cow per period. The previously listed dependent variables and the milk fatty acids concentration were analyzed including in the statistical model: period, treatment, and period $\times$ treatment interaction as fixed effects. Square and cow within square were included as random effects. Values reported are least square means. Significance was declared at $P \leq 0.05$, and a trend was reported if $0.05<$ $P \leq 0.10$.

\section{RESULTS AND DISCUSSION}

\section{DGS and Diet Characteristics}

The DGS was $88.3 \pm 1.0 \% \mathrm{DM}$ and contained (DM basis) $28.7 \pm 0.9 \% \mathrm{CP}, 25.9 \pm 2.3 \% \mathrm{NDF}, 14.7 \pm 1.7 \%$ $\mathrm{ADF}, 10.8 \pm 0.5 \%$ fatty acids, $13.8 \% \mathrm{EE}$, and $4.5 \pm 0.2 \%$ ash. Fatty acid composition of DGS was $0.1 \%$ of $\mathrm{C}_{14: 0}$, 
14.6\% of $\mathrm{C}_{16: 0}, 0.3 \%$ of $\mathrm{C}_{16: 1}, 2.6 \%$ of $\mathrm{C}_{18: 0}, 25.7 \%$ of $\mathrm{C}_{18: 1}$, $53.3 \%$ of $\mathrm{C}_{18: 2}, 1.6 \%$ of $\mathrm{C}_{18: 3}, 0.6 \%$ of $\mathrm{C}_{20: 0}$, and $1.2 \%$ other fatty acids. The NRC (2001) reported that DGS was $90.2 \pm 1.8 \% \mathrm{DM}$, and contained (DM basis) $29.7 \pm$ $3.3 \% \mathrm{CP}, 38.8 \pm 7.8 \% \mathrm{NDF}, 19.7 \pm 4.6 \% \mathrm{ADF}, 10.0 \pm$ $3.4 \% \mathrm{EE}$, and $5.2 \pm 1.1 \%$ ash. The EE concentration of the DGS used in the present experiment was 1 SD greater than the average value reported in NRC (2001). The NDF concentration of DGS was lower than the average value reported in NRC (2001). Clark and Armentano (1993) observed that DGS contained 31.5\% NDF when sodium sulfite was included in the procedure or $39.2 \%$ NDF when no sodium sulfite was used. Therefore, the laboratory methodology used may explain the lower NDF concentration.

Diets were formulated to have similar NDF concentrations, to be isonitrogenous, and to meet minimum RDP and RUP requirements according to NRC (2001). However, increasing dietary DGS inclusion rate mainly through the replacement of soybean meal and hulls (Table 1) increased dietary $\mathrm{CP}$ concentration by 0.4 percentage units (Table 2). After the experiment ended, chemical composition of forages, cottonseed, and DGS, average actual DMI, and milk production were included in the NRC (2001) model. According to the NRC (2001) model, RDP balance (RDP supplied - RDP required) was positive for all diets, whereas RUP balance was $+96 \mathrm{~g} / \mathrm{d}$ for $0 \%$ DGS, $+93 \mathrm{~g} / \mathrm{d}$ for $5 \%$ DGS, $-3 \mathrm{~g} / \mathrm{d}$ for $10 \%$ DGS, $-33 \mathrm{~g} / \mathrm{d}$ for $15 \% \mathrm{DGS}$, and $-81 \mathrm{~g} / \mathrm{d}$ for OIL. The decreased RUP balance was mainly due to an increased RUP requirement, in turn due to higher milk production obtained by increasing dietary concentration of DGS. After the experiment ended, the actual EE concentration of forages, cottonseed and DGS was included in the NRC (2001) model as total fatty acid concentration plus 1 (NRC, 2001). The model estimated dietary EE concentration to be: $4.1 \%$ for $0 \%$ DGS, $4.6 \%$ for $5 \%$ DGS, $5.2 \%$ for $10 \%$ DGS, $5.6 \%$ for $15 \%$ DGS, and $5.6 \%$ for OIL. The substitution of corn grain and soybean meal with DGS was not exactly proportional across diets. Therefore, the predicted EE change among treatments was not exactly linear; however, the fatty acid content of the $10 \%$ DGS diet (Table 2) appears to be an overestimate when compared with the fatty acid concentration of the 0,5 , and 15\% DGS diets and the NRC-predicted EE concentrations.

\section{Intakes, Milk Production, and Composition}

Dry matter intake did not differ significantly across treatments (Table 3 ). Increasing dietary concentration of DGS tended to increase NDF intake $(P=0.10)$. The numerically increased NDF intake was $0.2 \mathrm{~kg} / \mathrm{d}$ and was due to a higher dietary NDF concentration.
Feeding diets with increasing DGS concentration linearly increased milk production $(P=0.009)$, milk true protein yield $(P=0.002)$, and milk lactose yield $(P=$ 0.02 ). The addition of $15 \%$ DGS increased milk production by $1.6 \mathrm{~kg} / \mathrm{d}$ compared with 0\% DGS. When diets were initially formulated and DMI was predicted to be $26.9 \mathrm{~kg} / \mathrm{d}$ for all diets, the NRC (2001) model predicted a $2.2 \mathrm{~kg} / \mathrm{d}$ increase in $\mathrm{NE}_{\mathrm{L}}$ allowable milk feeding $15 \%$ vs. 0\% DGS. Therefore, the increased milk production was consistent with increased dietary energy density. Various studies have been conducted where DGS were fed. Feeding DGS did not always increase milk production. In 2 comparisons, substituting DGS for soybean meal increased milk production by approximately $1 \mathrm{~kg} /$ d (Powers et al., 1995; Nichols et al., 1998). The increased milk production was greater when the DGS were supplemented with rumen-protected methionine and lysine (Nichols et al., 1998). When dark and possibly heat-damaged dried DGS (Powers et al., 1995) or when wet DGS (Birkelo et al., 2004) replaced soybean meal, milk production did not differ between treatments. Birkelo et al. (2004) reported that the dietary inclusion of DGS increased not only dietary EE concentration from 3.1 to $5.1 \%$, but also dietary NDF concentration from 28.3 to $42.9 \%$; this increased NDF may have limited milk production responses.

In the present experiment, increasing the dietary percentage of DGS linearly increased the milk true protein yield by $50 \mathrm{~g} / \mathrm{d}$. A negative effect on milk protein yield was observed when DGS constituted approximately $30 \%$ of dietary DM and corn silage was the main forage source (Owen and Larson, 1991; Birkelo et al., 2004). The negative effect of feeding DGS was probably due to a lower supply of dietary lysine when corn (corn silage and DGS) and not soybean meal constituted a large portion of the diet. In other experiments, when either alfalfa was the major forage source or DGS constituted a lower dietary percentage, milk protein yield either did not differ among dietary treatments (Broderick et al., 1990; Powers et al., 1995) or was higher feeding DGS than soybean meal (Nichols et al., 1998). In the present experiment, diets were supplemented with blood meal and fish meal to minimize the possible negative effect of feeding a lysine-limiting diet. Addition of blood meal increased milk protein production in 2 reports (Armentano, 1992, 1994). Distillers grains diets containing blood did not respond to supplemental rumen-protected lysine (Armentano, 1992) and adding a fat-coated lysine supplement replicated the response to blood meal (Armentano, 1994).

The dietary inclusion of $1.5 \%$ (DM basis) corn oil also increased milk production by $2.6 \mathrm{~kg} / \mathrm{d}(P=0.005)$ and tended to increase milk true protein yield by $45 \mathrm{~g} / \mathrm{d}$ $(P=0.09)$. The increased milk production and milk true 
Table 3. Treatment effect on intake, milk production, and milk composition.

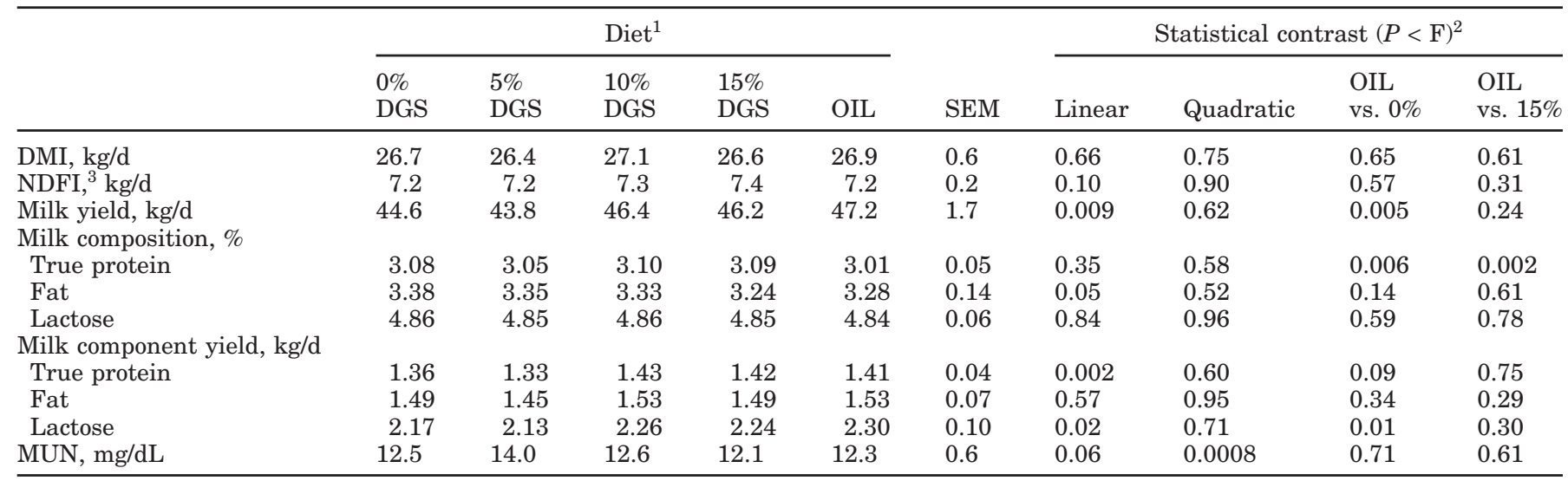

${ }^{1}$ Diets: $0,5,10$, or $15 \%$ DGS = diets containing distillers dried grains with solubles (DGS, DM basis); OIL = diet containing corn oil but no DGS; the amount of corn oil added was such that OIL and 15\% DGS had similar total fatty acid concentration.

${ }^{2}$ Statistical contrast: linear and quadratic effects of DGS and contrast between OIL and 0\% DGS and OIL and 15\% DGS.

${ }^{3} \mathrm{NDFI}=\mathrm{NDF}$ Intake.

protein yield was similar to the increase observed when feeding DGS. In fact, feeding $15 \%$ DGS vs. OIL had similar effect on cow productivity, except that milk true protein percentage decreased from 3.09 to $3.01 \%(P=$ 0.002). However, milk true protein yield did not differ between treatments. The similarity between OIL and 15\% DGS suggests that the response to feeding DGS was mainly due to the energy supplied by the corn oil present in DGS.

We hypothesized that increasing dietary EE concentration by increasing DGS would have decreased milk fat percentage and yield. Although increasing DGS inclusion rate linearly decreased milk fat percentage $(P=$ 0.05 ), milk fat yield was not different among treatments. Furthermore, addition of corn oil did not significantly affect milk fat percentage and yield, and fat yield was numerically highest with OIL. The inclusion of $4 \%$ (as-fed basis) of corn oil decreased milk fat percentage and yield when added to a diet containing $14.8 \% \mathrm{NDF}$ but not when added to a diet containing $32.1 \% \mathrm{NDF}$ (Griinari et al., 1998). In the present experiment, a lower amount of corn oil (1.5\%) and an intermediate level of dietary NDF concentration (27.8\%) were applied. Although cottonseed was also present in the diet, thus increasing the overall dietary EE concentration, the combination of these dietary characteristics was not sufficient to induce grossly apparent milk fat depression.

Milk urea nitrogen changed across diets (Table 3), being lowest when cows were fed 15\% DGS and highest when fed 5\% DGS. Various studies found that the best single predictor of MUN was dietary CP concentration (Broderick and Clayton, 1997; Nousiainen et al., 2004). However, in the present experiment, the changes in
MUN did not mirror the small changes in dietary CP concentration.

\section{Fatty Acid Composition of Milk Fat}

The dietary inclusion of either DGS or corn oil altered the fatty acid profile of milk fat (Table 4). Except for a few $\mathrm{C}_{18: 1}$ isomers and $\mathrm{C}_{18: 3}$, feeding either $15 \%$ DGS or OIL resulted in similar changes in fatty acid profile. Therefore, we believe that changes in fatty acid profile obtained in the present experiment from feeding DGS were due to the oil present in DGS.

Increasing DGS linearly decreased the percentage of shorter chain fatty acids $\left(\mathrm{C}_{10}\right.$ to $\left.\mathrm{C}_{16}, P<0.0001\right)$ and linearly increased the percentage of longer chain fatty acids, for example, $\mathrm{C}_{18: 0}(\mathrm{P}=0.008), \mathrm{C}_{18: 1}(P<0.0001)$, and $\mathrm{C}_{18: 2}(P<0.0001)$. Similar changes in milk fatty acid profile were observed in other experiments (Griinari et al., 1998; Schingoethe et al., 1999; Dhiman et al., 2000). Feeding $30 \%$ of dietary DM as wet DGS (Schingoethe et al., 1999), or $4 \%$ of dietary DM as corn oil (Griinari et al., 1998) or soybean oil (Dhiman et al., 2000) decreased milk fat concentration of short-chain $\left(\mathrm{C}_{4}\right.$ to $\left.\mathrm{C}_{13}\right)$ and medium-chain $\left(\mathrm{C}_{14}\right.$ to $\left.\mathrm{C}_{16}\right)$ fatty acids and increased milk fat concentration of long-chain fatty acids. Milk fatty acids of chain length $\mathrm{C}_{4}$ to $\mathrm{C}_{14}$ and approximately half of $\mathrm{C}_{16}$ are synthesized de novo in the mammary gland (Bauman and Davis, 1974). The remainder of $\mathrm{C}_{16}$ and longer chain fatty acids present in milk are derived from the diet or body reserves (Bauman and Davis, 1974). It was reported previously that increasing dietary concentration of long-chain fatty acid altered milk fatty acid profile by decreasing de novo fatty acid synthesis (Grummer, 1991). To verify if de novo fatty acid 
Table 4. Treatment effect on milk fatty acid profile.

\begin{tabular}{|c|c|c|c|c|c|c|c|c|c|c|}
\hline & \multicolumn{5}{|c|}{$\operatorname{Diet}^{1}$} & \multirow[b]{2}{*}{ SEM } & \multicolumn{4}{|c|}{ Statistical contrast $(P<\mathrm{F})^{2}$} \\
\hline & $\begin{array}{l}0 \% \\
\text { DGS }\end{array}$ & $\begin{array}{l}5 \% \\
\text { DGS }\end{array}$ & $\begin{array}{l}10 \% \\
\text { DGS }\end{array}$ & $\begin{array}{l}15 \% \\
\text { DGS }\end{array}$ & OIL & & Linear & Quadratic & $\begin{array}{l}\text { OIL } \\
\text { vs. } 0 \%\end{array}$ & $\begin{array}{l}\text { OIL } \\
\text { vs. } 15 \%\end{array}$ \\
\hline Profile & \multicolumn{5}{|c|}{$\longrightarrow(\mathrm{g} / 100 \mathrm{~g}$ of fatty acids $)$} & & & & & \\
\hline $\mathrm{C}_{4: 0}$ & 2.48 & 2.11 & 2.36 & 2.33 & 2.20 & 0.24 & 0.83 & 0.39 & 0.36 & 0.66 \\
\hline $\mathrm{C}_{6: 0}$ & 2.18 & 2.02 & 2.10 & 2.07 & 2.03 & 0.15 & 0.64 & 0.62 & 0.41 & 0.83 \\
\hline $\mathrm{C}_{8: 0}$ & 1.33 & 1.30 & 1.28 & 1.24 & 1.23 & 0.07 & 0.06 & 0.80 & 0.06 & 0.86 \\
\hline $\mathrm{C}_{10: 0}$ & 3.57 & 3.42 & 3.31 & 3.17 & 3.02 & 0.15 & $<0.0001$ & 0.94 & $<0.0001$ & 0.11 \\
\hline $\mathrm{C}_{12: 0}$ & 11.0 & 10.7 & 10.3 & 10.0 & 10.0 & 0.3 & $<0.0001$ & 0.86 & $<0.0001$ & 0.87 \\
\hline $\mathrm{C}_{14: 0}$ & 24.6 & 23.4 & 23.1 & 22.4 & 21.9 & 0.7 & 0.0001 & 0.62 & $<0.0001$ & 0.39 \\
\hline $\mathrm{C}_{16: 0}$ & 28.7 & 27.7 & 25.9 & 25.1 & 25.1 & 0.6 & $<0.0001$ & 0.81 & $<0.0001$ & 0.93 \\
\hline $\mathrm{C}_{18: 0}$ & 10.1 & 10.8 & 10.7 & 11.2 & 11.3 & 0.4 & 0.008 & 0.62 & 0.003 & 0.67 \\
\hline $\mathrm{C}_{18: 1}$ & 22.7 & 23.7 & 25.7 & 26.7 & 26.8 & 0.7 & $<0.0001$ & 0.94 & $<0.0001$ & 0.84 \\
\hline \multicolumn{11}{|l|}{$\mathrm{C}_{18: 1}$ isomers } \\
\hline Trans-4 & 0.01 & 0.02 & 0.02 & 0.02 & 0.02 & 0.003 & 0.30 & 0.15 & 0.32 & 0.84 \\
\hline Trans -5 & 0.02 & 0.02 & 0.02 & 0.02 & 0.02 & 0.004 & 0.17 & 0.37 & 0.48 & 0.50 \\
\hline Trans $-6+$ trans -8 & 0.33 & 0.38 & 0.42 & 0.44 & 0.49 & 0.05 & $<0.0001$ & 0.40 & $<0.0001$ & 0.03 \\
\hline Trans-9 & 0.29 & 0.33 & 0.36 & 0.39 & 0.41 & 0.04 & $<0.0001$ & 0.65 & $<0.0001$ & 0.28 \\
\hline Trans -10 & 0.79 & 0.98 & 0.95 & 1.25 & 1.30 & 0.39 & 0.004 & 0.56 & 0.002 & 0.77 \\
\hline Trans-11 & 0.86 & 1.21 & 1.50 & 1.66 & 1.77 & 0.13 & $<0.0001$ & 0.34 & $<0.0001$ & 0.47 \\
\hline Trans-12 & 0.98 & 0.66 & 0.71 & 1.32 & 0.77 & 0.27 & 0.04 & 0.27 & 0.59 & 0.12 \\
\hline Cis $-9^{3}$ & 18.1 & 18.2 & 19.7 & 19.8 & 19.9 & 0.6 & 0.0006 & 0.96 & 0.005 & 0.47 \\
\hline Cis-11 & 0.89 & 0.95 & 0.93 & 0.91 & 0.99 & 0.04 & 0.48 & 0.06 & 0.002 & 0.02 \\
\hline Cis -12 & 0.47 & 0.53 & 0.53 & 0.49 & 0.66 & 0.03 & 0.48 & 0.04 & $<0.0001$ & $<0.0001$ \\
\hline Cis-13 & 0.06 & 0.06 & 0.07 & 0.07 & 0.07 & 0.008 & 0.09 & 0.88 & 0.36 & 0.88 \\
\hline Cis $-14+$ trans -16 & 0.33 & 0.35 & 0.38 & 0.37 & 0.39 & 0.02 & 0.02 & 0.29 & 0.007 & 0.33 \\
\hline Cis-15 & 0.08 & 0.10 & 0.10 & 0.09 & 0.12 & 0.01 & 0.24 & 0.06 & $<0.0001$ & 0.001 \\
\hline $\mathrm{CLA}^{4} \mathrm{c} 9 \mathrm{t} 11$ & 0.45 & 0.60 & 0.77 & 0.83 & 0.89 & 0.05 & $<0.0001$ & 0.24 & $<0.0001$ & 0.29 \\
\hline CLA t10c12 & 0.01 & 0.02 & 0.01 & 0.02 & 0.02 & 0.003 & 0.36 & 0.82 & 0.12 & 0.69 \\
\hline $\mathrm{C}_{18: 2}$ & 5.04 & 5.38 & 5.90 & 6.17 & 6.17 & 0.24 & $<0.0001$ & 0.82 & $<0.0001$ & 0.99 \\
\hline $\mathrm{C}_{18: 3}$ & 0.37 & 0.35 & 0.32 & 0.31 & 0.36 & 0.02 & $<0.0001$ & 0.77 & 0.55 & 0.001 \\
\hline Other $^{5}$ & 6.26 & 6.13 & 5.88 & 5.73 & 5.57 & 0.18 & 0.0004 & 0.92 & 0.0001 & 0.34 \\
\hline Unidentified peaks & 2.6 & 2.7 & 2.4 & 2.3 & 2.5 & 0.1 & 0.001 & 0.07 & 0.73 & 0.03 \\
\hline
\end{tabular}

${ }^{1}$ Diets: $0,5,10$, or $15 \%$ DGS = diets containing distillers dried grains with solubles (DGS, DM basis); OIL = diet containing corn oil but no DGS; the amount of corn oil added was such that OIL and 15\% DGS had similar total fatty acid concentration.

${ }^{2}$ Statistical contrast: linear and quadratic effects of DGS and contrast between OIL and 0\% DGS and OIL and $15 \%$ DGS.

${ }^{3}$ cis-9 peak includes also trans-13, trans-14 and trans- $15 \mathrm{C}_{18: 1}$ isomers.

${ }^{4} \mathrm{CLA}=$ Conjugated linoleic acid.

${ }^{5}$ Others $=$ sum of $\mathrm{C}_{5: 0}, \mathrm{C}_{7: 0}, \mathrm{C}_{9: 0}, \mathrm{C}_{11: 0}, \mathrm{C}_{13: 0}$, iso $\mathrm{C}_{14: 0} \mathrm{C}_{14: 1}, \mathrm{C}_{15: 0}, \mathrm{C}_{15: 1}, \mathrm{C}_{17: 0}, \mathrm{C}_{17: 1}, \mathrm{C}_{19: 0}, \mathrm{C}_{20: 0}, \mathrm{C}_{20: 1}, \mathrm{C}_{20: 2} \mathrm{n} 6$, $\mathrm{C}_{20: 3} \mathrm{n} 6, \mathrm{C}_{20: 3} \mathrm{n} 3, \mathrm{C}_{20: 4} \mathrm{n} 6, \mathrm{C}_{20: 5} \mathrm{n} 3, \mathrm{C}_{21: 0}, \mathrm{C}_{22: 0}, \mathrm{C}_{22: 1} \mathrm{n} 9, \mathrm{C}_{22: 2}, \mathrm{C}_{22: 6} \mathrm{n} 3, \mathrm{C}_{23: 0}, \mathrm{C}_{24: 0}$, and $\mathrm{C}_{24: 1}$.

synthesis was reduced, we estimated yield of fatty acids as fat yield ( $\mathrm{g}$ of fat/d; Table 3 ) times the proportion ( $\mathrm{g}$ of fatty acid/g of total recovered fatty acids) of fatty acid reported in the profile (Table 4). Estimated yields of individual fatty acids followed the same pattern as the fatty acid profile (data not shown) indicating that, in the present experiment, the oil present in DGS reduced de novo milk fatty acid synthesis. However, the decreased yield of short-chain fatty acid coincided with an increased yield of long-chain fatty acid, resulting in no differences across treatments in milk fat yield.

The concentration of most C18:1 isomers, and in particular trans-10, was increased by adding either DGS or corn oil to the diet. Bauman and Griinari (2001) suggested the use of trans-10 $\mathrm{C}_{18: 1}$ as a marker of dietinduced milk fat depression. In the present experiment, the increased trans-10 $\mathrm{C}_{18: 1}$ milk fatty acid concentration did not coincide with a decreased yield of total milk fat. In the present experiment, the highest milk concentration of trans-10 $\mathrm{C}_{18: 1}$ was $1.3 \%$, which was less than half the concentration observed in the treatment that induced milk fat depression in Griinari et al. (1998). However, it is likely that in our study, trans$10 \mathrm{C}_{18: 1}$ or related fatty acids did decrease de novo mammary fatty acid synthesis to some extent, but that this decrease was offset by increased $\mathrm{C}_{18}$ fatty acid secretion derived from absorbed dietary long-chain fatty acids.

\section{CONCLUSIONS}

Feeding up to $15 \%$ DGS when the overall diet contains approximately $28 \% \mathrm{NDF}$ and $5 \%$ fatty acids in- 
creased milk and protein yield without decreasing milk fat yield. The composition of the milk fat was altered as the concentration of dietary oil from DGS or corn oil was increased.

\section{ACKNOWLEDGMENTS}

The authors thank the Wisconsin Corn Promotion Board for their financial support. Appreciation is expressed to the barn crew of the UW Emmons Blaine Dairy Cattle Research Center for animal care and feeding.

\section{REFERENCES}

Armentano, L. E. 1992. Determining the effectiveness of fiber in DGS when fed to lactating cattle. Distillers Feed Res. Counc. 47:99-106.

Armentano, L. E. 1994. How can we optimize the protein quality delivered to lactating cows when feeding distiller's drains? Distillers Feed Res. Counc. 49:63.

AOAC. 1990. Official Methods of Analysis. 15th ed. Association of Official Analytical Chemists, Arlington, VA.

AOAC. 1999. Official Methods of Analysis. 16th ed. Association of Official Analytical Chemists International, Gaithersburg, MD.

Bauman, D. E., and C. L. Davis. 1974. Biosynthesis of milk fat. Pages 31-75 in Lactation, a comprehensive treatise. Vol. 2. B. L. Larson and V. R. Smith, ed. Academic Press, New York, NY.

Bauman, D. E., and J. M. Griinari. 2001. Regulation and nutritional manipulation of milk fat: Low-fat milk syndrome. Livest. Prod. Sci. 70:15-29.

Birkelo, C. P., M. J. Brouk, and D. J. Schingoethe. 2004. The energy content of wet corn distillers grains for lactating dairy cows. J. Dairy Sci. 87:1815-1819.

Broderick, G. A., and M. K. Clayton. 1997. A statistical evaluation of animal and nutritional factors influencing concentrations of milk urea nitrogen. J. Dairy Sci. 80:2964-2971.

Broderick, G. A., D. B. Ricker, and L. S. Driver. 1990. Expeller soybean meal and corn by-products versus solvent soybean meal for lactating dairy cows fed alfalfa silage as a sole forage. J. Dairy Sci. 73:453-462.

Chouinard, P. Y., L. Corneau, D. M. Barbano, L. E. Metzger, and D. E. Bauman. 1999. Conjugated linoleic acids alter milk fatty acid composition and inhibit milk fat secretion in dairy cows. J. Nutr. 129:1579-1584.
Clark, P. W., and L. E. Armentano. 1993. The effectiveness of neutral detergent fiber in whole cottonseed and dried distiller's grains compared to alfalfa haylage. J. Dairy Sci. 76:2644-2650.

Dhiman, T. R., L. D. Satter, M. W. Pariza, M. P. Galli, K. Albright, and M. X. Tolosa. 2000. Conjugated linoleic acid (CLA) content of milk from cows offered diets rich in linoleic and linolenic acid. J. Dairy Sci. 83:1016-1027.

Goering, H. K., and P. J. Van Soest. 1970. Forage Fiber Analysis. (Apparatus, Reagents, Procedures, and Some Applications). Agric. Handbook No. 379. ARS-USDA, Washington, DC.

Griinari, J. M., D. A. Dwyer, M. A. McGuire, D. E. Bauman, D. L. Palmquist, and K. V. Nurmela. 1998. Trans-octadecenoic acids and milk fat depression in lactating dairy cows. J. Dairy Sci. 81:1251-1261.

Grummer, R. R. 1991. Effect of feed on the composition of milk fat. 1991. J. Dairy Sci. 74:3244-3257.

National Research Council. 2001. Nutrient Requirements of Dairy Cattle. 7th rev. ed. Natl. Acad. Sci., Washington, DC.

Nichols, J. R., D. J. Schingoethe, H. A. Maiga, M. J. Brouk, and M. S. Piepenbrink. 1998. Evaluation of corn distillers grains and ruminally protected lysine and methionine for lactating dairy cows. J. Dairy Sci. 81:482-491.

Nousiainen, J., K. J. Shingfield, and P. Huhtanen. 2004. Evaluation of milk urea nitrogen as a diagnostic of protein feeding. J. Dairy Sci. 87:386-398.

Owen, F. G., and L. L. Larson. 1991. Corn distillers dried grains versus soybean meal in lactation diets. J. Dairy Sci. 74:972-979.

Powers, W. J., H. H. Van Horn, B. Harris, Jr., and C. J. Wilcox. 1995. Effects of variable sources of distillers dried grains plus solubles on milk yield and composition. J. Dairy Sci. 78:388-396.

SAS Institute. 1998. SAS User's Guide: Statistic, Release 7th ed. SAS Inst., Inc., Cary, NC.

Schingoethe, D. J., M. J. Brouk, and C. P. Birkelo. 1999. Milk production and composition from cows fed wet corn distillers grains. J. Dairy Sci. 82:574-580.

Spiehs, M. J., M. H. Whitney, and G. C. Shurson. 2002. Nutrient database for distiller's dried grains with solubles produced from new ethanol plants in Minnesota and South Dakota. J. Anim. Sci. 80:2639-2645.

Sukhija, P. S., and D. L. Palmquist. 1988. Rapid method for determination of total fatty acid content and composition of feedstuffs and feces. J. Agric. Food Chem. 36:1202-1206.

Van Soest, P. J., J. B. Robertson, and B. A. Lewis. 1991. Methods for dietary fiber, neutral detergent fiber, and nonstarch polysaccharides in relation to animal nutrition. J. Dairy Sci. 74:35833597.

Wisner, R. N., and C. P. Baumel. 2004. Will there be enough corn to supply future needs? Feedstuffs 76(30):15. 